\title{
Vou fazer o que em casa?
}

\author{
Abdias Vilar
}

Em 2001, realizamos entrevistas ${ }^{1}$ com 49 aposentados do Serviço Público Federal nos Estados de Paraíba, Pernambuco, Paraná, São Paulo e do Distrito Federal. Desse total, 28 eram mulheres e 21 homens, sendo 28 casados, 10 solteiros, 6 viúvos e 5 divorciados. Em relação à situação funcional, 37 pertenciam ao quadro de nível superior e 12 de nível médio. No momento da aposentadoria, 87,75\% estavam com idade entre 42 e 59 anos, enquanto $12,25 \%$ na faixa superior a 60 anos.

$\mathrm{Na}$ construção das expectativas da aposentadoria, uma das primeiras inquietações, reveladas como balizamento para uma nova vida, surge através da interjeição indagativa "Vou fazer o que em casa?", que ganha entonações diferentes na voz feminina e na voz masculina.

A metáfora da casa é referência identitária e possui várias "esferas de significação social” (DaMatta, 1991, p. 53). Através dessa metáfora queremos apreender toda complexidade do "zoneamento do tempo-espaço em relação às práticas sociais rotinizadas" e dessa forma darmos conta da "mutualidade de presença e ausência" (Giddens,1989, p. 96 e 95).

A volta ao lar pode significar recolhimento, isolamento, dedicação exclusiva ou majoritária às rotinas de uma vida familiar. Receio expresso através de outras duas expressões: "Ficar o tempo todo em casa, Deus me livre"; "o que vou fazer com você em casa o dia inteiro sem fazer nada".

\footnotetext{
* Doutor em Ciências Sociais pelo IFCH/ UNICAMP e Consultor Social.

1 A conclusão da pesquisa foi apresentada como tese de doutorado O caminho do tempo: trajetória de vida do Serviço Público Federal (Vilar, 2002.).
} 
São frases repetidas, sob risos e reticências, sob tonalidades masculinas ou femininas, que flexibilizam as tensões de uma convivência diária a tempo integral. Nestas frases está o desafio de uma nova forma de convivência e relacionamento da família na família. Se antes a luta incessante era para conciliar trabalho e família, agora são, em princípio, 24 horas face a face, onde todos os aspectos da cotidianidade serão partilhados coletivamente. De um convívio social extensivo em vários espaços e tempos diferentes e distintos, passa-se, sem nenhuma preparação e de forma até repentina, para uma dedicação quase exclusiva às relações sociais primárias: a família e o lar como centro de todas as convergências. Há uma concentração espacial e de temporalidades novas na casa, que a torna efetivamente ponto de chegada e de permanência, não mais "estacionamento", passagem.

Não insinuamos apenas as dificuldades da rotina do casal, da família a adaptação e alteração de hábitos, os conflitos, mas as dificuldades de articulação e convivência, em uma palavra, a sincronização dos múltiplos tempos, das presenças e ausências, do estritamente localizado até o externo, e neles a probabilidade do risco de uma maior demanda para aquele que está com "o tempo livre":

Ele (o aposentado) é visto completamente à disposição de todo mundo, porque seu tempo é livre. Então dão a ele todos os trabalhinhos dentro de casa porque ele é aposentado. (S.N.M., aposentada).

Tive que me preocupar, muito pouco é verdade, com a possibilidade de ser visto, por familiares, amigos, vizinhos, etc. como alguém desocupado, a quem podem ser atribuídas tarefas com as quais os 'ativos' não podem perder tempo. Felizmente, não passou de pequena preocupação, sem concretização. (P.I.V., aposentado).

Por exemplo, algumas amigas deixam de usar o carro porque outra pessoa quer usar. Eu tenho uma amiga que dá o carro para os filhos passearem e fica em casa porque está aposentada. Eu não faço a menor questão de servir, mas eu estou na frente. É muito fácil chegarem para mim e dizer que já que estou desocupada posso fazer as coisas, mas eu faço até a hora que eu quiser. (G.M.T.A., aposentada). 
Parece que a gente fica com menos tempo depois que se aposenta. Naquela rotina de trabalhar, assinar ponto, levar e buscar menino na escola, esse ritmo parece que faz a gente multiplicar o tempo. Depois, a gente fica com o tempo à disposição de todo mundo. (N.Z.F., aposentada).

O aposentado é visto "à disposição de", como se ele não tivesse seus interesses e desejos; como se o seu tempo não lhe pertencesse com exclusividade, na melhor das hipóteses, é fracionado para que todos possam dele usufruir. Em outras palavras, o tempo livre está em função do tempo dos que o cercam, não do aposentado. Visto do ângulo oposto, a dedicação aos outros não estaria ocultando um sentimento de culpa ou de resignação?

\section{A reprodução ampliada da jornada de trabalho}

Na voz feminina, o "fazer o que em casa" é continuidade ampliada da dupla jornada, pois até fisicamente a casa lhe é mais costumeira, onde sempre lhe coube o papel de zeladora desse locus geográfico-social-político; é "colaboração" para a manutenção de um certo padrão de vida dos filhos; e "redenção" de um conflito interno.

P: O que mudou em sua vida nos sete anos de aposentada?

R: A minha vida era muito corrida, muito preenchida em termos profissionais. Mesmo quando, por exemplo, eu estava em casa, o que eu fazia era com horário muito corrido em função do trabalho. A minha atividade principal era o trabalho e não a casa. Apesar de minha ligação afetiva com a casa. Eu sempre estive muito presa emocionalmente, afetivamente a casa. $\mathrm{O}$ trabalho não era $\mathrm{o}$ primeiro plano para mim não, mas na realidade, no dia a dia, eu desenvolvia muito mais atividades, era muito mais preenchido lá do que aqui. Isso mudou muito porque eu parei completamente. Passei a me dedicar $24 \mathrm{~h}$ a casa. A mudança principal foi esta.

P: O que significa $24 \mathrm{~h}$ em casa?

R: Eu passei a fazer todos os trabalhos domésticos. Saio pouco. Não me dediquei a outra atividade. Às vezes, eu passo a semana só resolvendo as coisas de casa, o dia a dia, a rotina. Saio, assim, 
vamos dizer, para fazer feira, um supermercado, a uma missa, tenho um compromisso com a parte religiosa, mais nenhuma atividade extra casa. Eu digo $24 \mathrm{~h}$ porque, às vezes, são 11 horas da noite e eu estou esperando filho que está chegando, fico naquela preocupação, ansiedade, só esperando. Só vou dormir na hora em que as coisas se acomodam, se organizam ou ao contrário como hoje. C..., minha filha, ia sair às cinco horas da manhã, só que se levantou e passou mal. Ela me chamou, então, às cinco horas eu comecei a atividade em função dela, embora depois tenha voltado um pouquinho para cama.

P: Você sai da dedicação exclusiva ao trabalho para dedicação exclusiva à família?

R: Não era exclusiva porque, por exemplo, quando eu tinha empregada... Passei bastante tempo da minha vida tendo empregada, então eu fazia em casa coisas que só me agradavam. O resto deixava para a empregada e quando chegava muita coisa estava pronta. Eu só assumia a casa mesmo quando estava sem empregada doméstica, que para mim era um fator importante. As meninas pequenas precisavam de atenção, de alguém, na minha ausência. (C.M.C.V., aposentada).

Numa contabilidade social das ações familiares, o tempo do aposentado teria a função de um "surplus" que se concretiza através de: a) assumir determinadas tarefas domésticas, antes delegadas a terceiro, em virtude do "encurtamento" do poder de compra do seu salário, sobretudo em momentos de crise econômica, caracterizada pelo arrocho salarial, como por exemplo, a dispensa da empregada doméstica; b) viabilizar a presença no mercado de trabalho de membro da família através de determinadas colaborações, ajudas, encargos, como, por exemplo, cuidar de netos pela impossibilidade financeira de contratação de uma babá ou de colocá-los numa creche ou escola; e c) acolher a volta de filhos para residir dentro da própria casa paterna seja por motivo de separação conjugal seja por desemprego. ${ }^{2}$ A casa reveste-se de uma feição de extensão do

2 Dois pais conversando, um assim se expressou: "meu filho ficou desempregado, voltou lá para casa com mulher e filho. Acham que por estarmos aposentados, podem tudo. É a vida. Mas, a casa é também deles!" 
tempo livre dos pais. A identidade familiar nuclear se conforma à identidade familiar ampliada. Em sua própria casa ou em função dos filhos, o seu tempo "de atividades" não é integrado como custo, ele está "disfarçado" na contabilidade geral, porém a sua colaboração é quem viabiliza um padrão familiar. Sem a consciência de uma organização de economia familiar, o aposentado e mais ainda a aposentada desempenham um papel importante na estratégia de um padrão de vida, não permitindo que a degradação chegue a um nível inferior.

Pois se para algumas aposentadas é continuidade de uma prática tradicional, agora redimensionada em grau superlativo absoluto, para outras é início com grandezas mais extensas.

Eu preparei meus filhos o tempo todo dizendo que agora o meu tempo era para descansar, e cada um que tiver seus filhos que se vire. Só que vi o que está se sucedendo muito na minha classe toda: viver na obrigação de cuidar dos netos. O que está acontecendo é que a gente viveu num tempo em que tinha condições de arrumar uma pessoa para cuidar dos filhos, mas agora é dificílimo; apesar do número de empregadas se oferecendo, é até uma contradição, mas é muito difícil você achar. E as pessoas têm outro esquema de vida. Minha filha, por exemplo, não tem cozinheira nem nada e não pode voltar para casa na hora do almoço. Então tive que ficar com meu neto e era mais um aspecto de dizer que eu estava fazendo alguma coisa.

Uma coisa, que não posso dizer a você que lamento, mas foi o tempo que eu e meu marido poderíamos nos dar ao luxo de viajar. É uma coisa que sabíamos fazer: eu viajei duas vezes nas férias para a Europa por conta própria, e ele viajou, a serviço, para a África e para Portugal. Nós passamos dois anos nos Estados Unidos, tive licença porque ele foi fazer o mestrado em eletricidade. Então, as viagens dele foram programadas a serviço, e eu viajei porque gosto de viajar. Agora, quando poderíamos viajar juntos, não podemos. (L.A.L., aposentada).

Esse relato de uma servidora pública aposentada com nível superior, aos trinta anos de serviço, tendo certamente incorporado ao salário todas 
as gratificações pelo exercício de chefias, vive com seu esposo, também de nível superior, aposentado. O casal tem três filhos, um é engenheiro, outra é médica (casada), "trabalha feita uma condenada", tem consultório e emprego público, "ganha um décimo dos outros" e a outra filha, formada em engenharia elétrica "por causa do pai, ela é louca pelo pai -, tem mestrado em Direito e trabalha agora como analista financeira de um banco me telefona às vezes da Colômbia, Buenos Aires, Nova York". Essa família, típica de classe média, revela as dificuldades financeiras em que vive hoje a maioria dos aposentados, e no nosso caso, dos aposentados públicos. No seu depoimento distinguimos um pudor para demonstrar os "apertos" financeiros e um atributo ao tempo que se substantiva no cuidar dos netos: "para dizer que estava fazendo alguma coisa".

Se as falas acima transcritas são expressões de um grupo social de classe média em dificuldades para manter o padrão de vida anterior, especialmente se considerado como símbolo a empregada doméstica, que o eufemismo denomina de secretária, nem por isso poderemos dizer que, em geral, em famílias que mantém um padrão mais elevado, não estejam as mulheres dedicando um tempo para a administração da casa, dos cuidados familiares, como decorrência da divisão, ou noutro eufemismo, da distribuição das lides familiares. Se para algumas mulheres o trabalho doméstico é o lavar, passar, cozinhar; para outras é a administração, no sentido do planejamento e da fiscalização, por isso desfruta de um status mais valorizado; todavia, todas as especializações fazem parte do sistema de reprodução da condição feminina no lar, quer como dona de casa, quer como profissional / dona de casa.

Em alguns momentos das entrevistas, várias pessoas se emocionaram ao falar de um controle financeiro que estão sendo obrigadas a fazer, inclusive médicas, tendo modificado o padrão de vida, limitando-se hoje ao essencial. O lazer é o primeiro a ser sacrificado, ficando restrito aos encontros familiares, assistir televisão em casa, aluguel de vídeo, e para os homens, campo de futebol. Os passeios, especialmente viagens mais longas, sonho de todo aposentado, foram cortados: "Poder viajar com meu marido, coisa que nunca realizei enquanto trabalhava, pois minhas férias eram dedicadas aos meus filhos" (J.C.S.). As assinaturas de jornais e revistas ou não foram renovadas ou drasticamente reduzidas a uma assinatura.

Claro que a situação econômica e financeira do país, na época, alterou os projetos desenhados para o gozo da aposentadoria, substituindo-os 
por uma certa carga de frustração, conforme ouvimos em declarações que nos ajudam a compreender o atual estado de vida dos aposentados:

Ter muita tranqüilidade e aproveitar muito para viajar. Estabilidade econômica para fazer milhões de curso que queria e não tinha tempo e que agora é mais impossível ainda, por falta de recursos financeiros. As expectativas ficaram frustradas, você tem todo o tempo do mundo e não tem o que fazer com ele. (P.D.M., aposentada).

Fase em que vivo de maneira simples e parcimoniosa conforme os vencimentos que percebo. (H.I., aposentada).

Hoje não posso dizer que tenha a mesma disponibilidade financeira do momento da aposentadoria. Quase sete anos sem aumento! E qualquer coisa, o curso, por exemplo, vai requerer algum gasto. Atualmente no meu orçamento não está cabendo mais nada. (A.M.L.S.M., aposentada).

Todo mês eu entro no CDC-salário, pago aquela quantia, faço em 12 meses, 18 meses, enquanto eu posso pagar, entro no limite. Meu Deus, eu nunca vivi assim, eu era para estar louca, graças a Deus eu tenho esperança. Eu tenho sempre esperança no dia de amanhã, vai melhorar; a gente não vai ficar assim. É em Deus que estou acreditando, mas quero acreditar nos poderes públicos também, mas não vejo por onde, não votei nele [refere-se a Fernando Henrique Cardoso], nem da primeira vez, porque estava no Rio Grande do Sul, nem da segunda, porque não gostei dos quatro anos. (M.A.N., aposentada).

A aposentadoria é hoje para mim 60\% de minha renda total, porque com essa defasagem de salário que vem acontecendo eu não poderia sobreviver pura e simplesmente com a aposentadoria que tenho do serviço público. Então a minha atividade econômica paralela é para complementar a minha renda, embora eu saiba que tenha perdido um percentual significativo do meu padrão de vida que mantinha. (R.J.G.C, aposentado). 
Nessa "volta ao lar" a tradição se renova e se reproduz. O espaço do lar parece ser portador de uma estrutura hierárquica na família. Com a aposentadoria aumenta consideravelmente tanto em projeção quanto em possibilidade real a utilização do tempo livre para as atividades domésticas. É como se a aposentadoria "desencantasse" esse caráter da dupla jornada, se confundido inteiramente com ele. Rasga-se o véu, a realidade está nua e crua exposta, refeita diariamente por solidez estrutural, por necessidade financeira e por oportunismo conservador.

\section{"Descobri que tinha uma casa"}

Para a mulher, a aposentadoria é também um desejo para construir novas formas de vida, desde o assumir a casa, como local doméstico, até alternativas de trabalho. Nessa estrada da vida do aposentado o "fazer o que em casa" é estação também de prazer, de redescoberta e resgate do eu, do nós:

Eu passei a tratar do físico, com atividades que antes não podia; dormir e me alimentar melhor. Ter mais tranqüilidade para viver. Isso mudou meu relacionamento com minha família, meu marido e tudo. (M.I.B).

Descobri que tinha uma casa, não é? Aprendi a fazer um arroz, feijão, etc. Não agüentei mais a empregada, que já tinha passado quase dez anos... Deixe-me dizer sim mais outra coisa: eu, a essa altura não me pertenço; primeiro para o neto que são 12 horas, tirando o tempo que ele está na escola, eu aproveito para fazer alguma coisa, além da casa, o trabalho voluntário... (L.A.L).

Ser literalmente dona de casa, cozinhar, lavar, passar, enfim ter a rotina de um lar e dedicar-me a alguma forma de voluntariado. (J.C.S).

Significa investir no que nunca pude fazer: curtir o doméstico que me faz muito bem... desenvolver atividades de prevenção à saúde, poder ter mais participação político-cultural, de vez em 
quando ir para o interior, ir a festa sem preocupação com o dia seguinte, até ter o direito de ficar em casa lendo, lendo, costurando, ouvindo música... Isso. (S.M.N.).

Me sinto bem em estar dentro de casa, cuidando da minha casa, eu gosto; sou uma pessoa que procuro viver bem onde estiver. Se estou em minha casa, procuro limpar, cuidar das minhas coisas, costurar, bordar, tudo isso eu sei fazer, ocupa muito o tempo e além de cuidar da minha casa, eu tiro o meu tempo de lazer para ler. Eu vou para o Centro (Espírita) onde eu presto minha contribuição fazendo enxovais... (M.M.J., aposentada).

Na maioria das vezes, a casa como local doméstico ficou por muito tempo entregue às empregadas, em conformidade com o status social, com as possibilidades financeiras de cada momento e com a postura ideológica adotada.

No corre-corre do trabalho, delegamos as funções às pessoas que trabalham conosco em casa, mas ficamos pensando que estamos explorando essa pessoa porque estamos em casa, parados. Essa possibilidade de pensar em bem estar físico, hidroginástica, caminhadas, sem preocupação com o tempo, isso nos fez refletir se não estava sendo o ócio. Se seria necessário mesmo ter uma pessoa em casa, se você estava desocupado. Antes era preciso porque não estava em casa, e agora que estou? O repensar e o retorno a esse ócio voltado para uma atividade, artesanato, por exemplo, usar o tempo livre para criar, visitar um museu, ir ao cinema. A idéia que se tinha era que lugar de mulher aposentada é na cozinha, temos que repensar esses conceitos, mas sem se deixar envolver por essas preocupações. Esse repensar é que é importante no primeiro momento da aposentadoria, que você dispõe de todo tempo livre que nunca teve antes. É ser feliz e saber ser feliz. (M.M.I.T., aposentada).

Normalmente, era nos fins de semana e nos feriados que a mulher se voltava para "cuidar da casa". De toda forma, estava em casa, estavam em casa. Ela agora se vê diante de uma segunda descoberta, mas com 
posse definitiva, de algo que lhe era e é tão íntimo. Posse definitiva que inclusive é assumida, simbolicamente, pelos atos que circunscrevem as funções ditas femininas.

A casa, "cenários de interação", na formulação de Giddens, está cheia de forças do pensar, do agir, do querer e do poder. Por essas manifestações, ela é, primeiramente, a localização do encontrar-se consigo mesmo dentro de uma atmosfera grupal para viver sua individualidade e seus múltiplos papéis sociais, é a partir dela que se irradiam as demais ações. É essa deslocação que caracteriza e diferencia o tempo do aposentado da vida anterior de servidor público.

Não se deve deduzir que todas as mulheres aposentadas se dedicam exclusivamente aos assuntos domésticos. Se ressaltamos a divisão doméstica do trabalho, é porque na aposentadoria ela não é eliminada, reproduz, ampliando o que existe na sociedade como pensamento, como ideologia, como ato concreto. Outras ocupações, com maior regularidade, tendo um sentido de compromisso institucional ou uma atividade voluntária carregada de valor moral, fazem o tempo da aposentada:

Hoje, depois que assinei um contrato permanente com a iniciativa privada, parece que volto a sentir que renascem novos vínculos com a sociedade, com um projeto coletivo. (L.M.E.M.F., aposentada).

Colaboro com atividades de trabalho manuais e bordados para rede do Câncer de minha cidade. Pertenço ao grupo de bordados para AACD. Participo e colaboro com as atividades religiosas da minha Igreja. (T.M., aposentada).

Também tenho dedicado um tempo ao trabalho voluntário. [...] Mas há a preocupação, sempre presente, de conseguir outra atividade que também remunere, pois aposentadoria não permite manter o padrão. (C.M.M.L., aposentada).

Realizada não tanto, eu ainda gostaria de trabalhar com plantas (com finalidades fitoterápicas), isso poderia ser também uma realização pessoal e também uma realização financeira, devido à minha situação financeira de hoje. (M.M.J., aposentada). 
Interessante se frisar "esse novo vínculo com a sociedade" que provém do trabalho, capaz de despojar a individualidade para trazer com ele o valor do coletivo. A ideologia sobre o trabalho como fonte de realização social, de meio de integração, de legitimação de um tempo livre continua como justificativa.

O voluntariado, ação pessoal de colaboração para com o próximo, "outro dia um amigo me pediu para ver sua tia, que está sofrendo uma coisa, que nenhuma análise resolve, uma solidão. Eu fiz uma primeira visita e fiquei contratada..." (L.A.L.) aparece também na vida do aposentado como desejo de retribuição do que aprendeu, tendo, portanto, um significado moral e fonte de legitimação social.

$\mathrm{Na}$ sociedade atual, o trabalho voluntário para a terceira idade é louvado como integração social e terapia, o que a torna objeto de sua própria ação. Ele assume a forma de uma ação espontânea ou mais sistematizada, com determinadas obrigações.

Ao se engajar no trabalho voluntário, por muito tempo visto como ação de velhos ou de pessoas ligadas à igreja, daí o seu universo ficar circunscrito às igrejas, asilos, hospitais, o aposentado deseja estar antenado com a sociedade. No entanto, apesar da ideologia da valorização da terceira idade e de uma nova concepção do voluntariado como ação política (cidadania), na realidade concreta o trabalho voluntário se apresenta, muitas vezes, com propostas não muito definidas, ${ }^{3}$ gerando uma frustração pela improvisação ou pelo uso inadequado da capacidade do aposentado, que passa a enxergar nessa nova atividade apenas a utilização barata de sua mão-de-obra.

Pelos depoimentos, mesmo não havendo uma quantificação, podemos até considerar como hipótese que o trabalho voluntário está presente mais nas práticas femininas do que na masculina, e de que está majoritariamente ligado à formação profissional do aposentado, de tal forma que os que têm curso superior buscam se dedicar mais às atividades de planejamento, de assessoria, de ensino e reflexão; as atividades mais

3 De uma aposentada sobre as dificuldades para o trabalho voluntário: “Quando eu me aposentei, achei que seria mais fácil eu me oferecer como voluntária. Seria uma coisa que poderia me apresentar um resultado mais concreto. E nas varias tentativas que fiz foi muito difícil. [...] Eu não queria ser mera mão de obra em distribuição de cestas básicas, por exemplo, no que isso vai me levar à frente?” 
domésticas como costurar, bordar, organização de exposições artesanais, ficam para os que não têm formação universitária.

Dos entrevistados do sexo masculino, apenas um se dedica ao trabalho voluntário, como rotariano, no Instituto do Cego e em um educandário para palestras sobre "questões ambientais" (Q.H.A.).

\section{A voz masculina: dedicação à família}

Na voz masculina, "fazer o que em casa?" tem outra conotação menos ampla do que na voz feminina, que junta lar, residência e família num mesmo horizonte, locais distintos num mesmo espaço. Para o homem, o primeiro significado é de reconhecimento de sua inutilidade para as duras atividades domésticas, que por conseqüência o é de reafirmação da divisão sexual do trabalho e do seu status de macho na sociedade. Cozinhar o extraordinário, fazer supermercado, levar-buscar filhos e netos na escola, bricoler já são avanços do homem moderno, ou urbanizado, e que aí pararam, pelo menos tomando como fonte o que foi colhido nas entrevistas. Assim, a casa surge como o oposto à falta de novas oportunidades de trabalho ou de outra ocupação:

Eu não queria me aposentar porque aqui fora as perspectivas de emprego eram as piores possíveis... Eu via aqui fora uma situação dificílima, eu vou me aposentar e $V$ ou fazer o que em casa? (C.M.P.T., aposentado).

Eu acho que a minha aposentadoria (significado) foi mais no ponto de vista social, mais em termos de família. Na realidade eu tenho mais tempo agora para me dedicar à família e à nova turma que está chegando, os netos. (S.H.S., aposentado).

No universo de nossa pesquisa, 21 entrevistados são do sexo masculino, em apenas um o compromisso com atividades domésticas é assumido explicita e prazerosamente:

R: A relação minha com minha mulher é muito equilibrada. É bom porque eu ajudo muito a ela, entendeu? O apoio logístico eu 
dou a ela, todo dia ela diz que a melhor coisa do mundo é ter um marido aposentado. Ela diz:: "vai fazer isso para mim", aí eu vou, resolvo os problemas dela e tudo, quem quebra os galhos dela sou eu, aí tudo de casa quem resolve sou eu, aí eu tenho um apoio logístico muito grande a ela. E em casa quem faz tudo sou eu, tudo, coloco roupa pra lavar, quem ajeita tudo em casa sou eu.

P: Que antes não fazia isso, quem fazia era ela?

R: Não. Era ela. Tudo mudou, eu odeio empregada dentro de casa, às vezes ela quer colocar empregada: não! Eu limpo, encero, quem lava tudo sou eu, na máquina, tudo quem faz sou eu em casa, almoço, adoro cozinhar, eu sempre gostei de cozinhar; [...] quando ela fica em casa no sábado e no domingo aí eu cozinho, mas durante a semana eu dou dinheiro ao menino e ele vai e come, eu também, na rua; volto, venho ler, dormir... (S.J., aposentado).

Para os demais, a aposentadoria é o momento, a oportunidade de mais dedicação à família nuclear e ampliada. Dedicação que se reveste de uma constante presença junto aos filhos, quando ainda estão em casa, ou aos netos, o que é feito pelo ato de levar e buscá-los na escola, nas aulas de língua, de natação; de fazer as compras de supermercado, e ficar mais em casa. A novidade agora é que na sua agenda sem horas haja mais horas para algumas atividades que se tornaram compromissos familiares. Observando bem, verificamos que o homem utiliza a expressão "dedicação à família” distinta, portanto, de trabalho, afazeres domésticos. Estar mais em casa não é a mesma coisa de assumir as atividades domésticas. É estar com a família.

Essa diferenciação de papéis sociais não sofre grandes alterações com a chegada da aposentadoria, pelo contrário, por estar já sedimentado e sacramentado pela tradição civil e religiosa é encarado com naturalidade:

P: Você acha que há uma diferença entre a mulher aposentada e o homem aposentado?

R: Eu acho até pela estrutura normal que se vê do homem e da mulher. O homem aposentado, eu tenho a minha experiência porque o meu marido é aposentado e não conheço outros (Risos). Ele em casa, por exemplo, me ajuda. Ele é uma pessoa extremamente doméstica. Ele seleciona, ele faz uma seleção do que 
quer fazer e eu acho ótimo. Sempre digo qualquer ajuda é bem vinda das meninas ou dele, mas em geral a dureza, eu não tenho escolha. As pessoas fazem alguma coisa até ali, até aqui é bom de fazer, é gostoso, eu faço porque eu quero. Dali em diante deixa, então, eu pego o lado ruim de alguma coisa doméstica, por exemplo, e o homem não. Ele faz quando quer, se é prazeroso, gostoso para ele, se é interessante; se não, senta-se para ler o jornal, ou vai sair, se senta lá embaixo ou para outro lugar. Quer dizer, tem mais liberdade de ação. Eu não sei se são todos, por isso que eu estou dizendo, a minha relação com meu marido é essa. Ele tem mais liberdade de dizer eu vou, eu faço ou eu não faço. (C.M.C.V.).

Acho que deve haver uma diferença muito grande, porque a mulher sempre tem a casa, aí diríamos como Nelson Rodrigues 'as normais', e se ela tem a casa, ela tem milhões de afazeres; agora os homens, eu soube que o que tinha de homem depois de aposentado numa sala que era dos Recursos Humanos, iam quase todos os dias, então é diferente, é muito diferente. O meu marido não, graças a Deus tem uma cuca ótima. No momento ele é curador da Fundação, eu às vezes fico com raiva porque ele diz que hoje eu não posso sair porque ele vai passar o dia na Fundação. (L.A.L.).

A domesticidade do homem é seu mando, é sua posição superior de entrar-ficar-sair-voltar quando bem entender; é sua liberdade de escolher o que, quando e como fazer, ou melhor, o que, quando e como ajudar. Para a mulher, a responsabilidade é integral não ter escolha resta-lhe em geral a "dureza", a "normalidade" rodriguiana. Para o homem, o tempo doméstico é prazer, usa quando lhe convém, até mesmo daquele que gosta e assume as tarefas de casa, pois quando está “de veneta” nada faz. Já para a mulher há uma responsabilidade que lhe é cobrada não só pelos membros da família, mas pela sociedade em geral.

Permanecer em casa é para o homem estado de carência, de falta de ocupação mais produtiva. Por isso que à rua, para utilizar a célebre relação casa/rua feita por DaMatta, serão dados atributos como espaços do que fazer, que não lhe afetam a dignidade de homem, de chefe de família: ir ao banco, ao supermercado, ao local de trabalho, encontrar-se com amigos. Esse "fazer" é um fazer poroso. É o agüentar-se para atenuar a 
fadiga do "o que vou fazer com você em casa o dia todo". Assim, "o tempo passa sem se sentir que nada fez, parecendo que tudo foi feito" poderia ser muito bem um epílogo na voz de muitos e muitos aposentados:

Sou uma pessoa metódica, eu tenho hora... eu vou ao supermercado todo dia duas vezes: de manhã e de tarde; de manhã compro coisas que é da manhã, à tarde é da noite e para o outro dia; eu acho que é por não ter o que fazer e você tem que preencher seus dias, é o inconsciente, não é? (S.J., aposentado).

Se prestarmos bem atenção ao comportamento de determinados aposentados em locais públicos, como por exemplo, em filas de banco, veremos que muitos deles fazem desse constante comparecimento o seu preenchimento do dia a dia, motivo para trocar conversa e opiniões sobre o país, a política, o futebol, a violência. $\mathrm{O}$ autor deste artigo testemunhou, em 2001, e em momentos diferentes, dois fatos em filas de banco e supermercado. Primeiro, um aposentado aproxima-se do caixa deixando para trás um bom número de pessoas. Diante de um psiu bastante forte, ele olha para o mais próximo e rindo diz: "pode ir, eu não me incomodo, tenho todo tempo, sou aposentado mesmo. Tenho tempo para vir quantas vezes quiser". Retira-se sem constrangimento, para pouco depois já estar olhando o tamanho da fila, mas por fora dela. No segundo caso, um senhor corta a fila e posta-se atrás de alguém que está realizando uma operação bancária. Outro senhor, na fila, grita: "que é isso, olha a fila, é muito cara de pau". Ele simplesmente aponta para o cartaz indicador de acesso privilegiado e diz: “tenho direito. É o direito". O reclamante responde: "eu também sou aposentado, mas não vou usar esse privilégio, a fila está pequena, não é nada urgente". O outro replica: “cada um usa o seu direito como quer". Tira seu extrato, sai e ao passar por mim, certamente pelos meus cabelos brancos: "vá, é um direito".

Estes casos, como em tantos outros episódios corriqueiros, revelam uma concepção pragmática do direito, a lei existe e pouco importa se o caso seja urgente ou não, se a fila, grande ou não; uma forma de ocupação, "tenho todo tempo"; e uma identificação, ao assumir sua condição de idoso, o que nem todos fazem. Para alguns aposentados são esses atos simples que lhes preenchem o vazio das horas e dão sentidos a sua cotidianidade. 
"Fazer o que em casa?" traduz medo do ócio, do nada fazer que possa conduzir ao isolamento, ao tédio, à inutilidade. Para muitos, a presença coletiva é solidão sozinha. Olhar e entreolhar-se entre quatro paredes como "estátuas pensantes" da parábola narrada por Elias:

Cada estátua forma sua própria opinião. Tudo o que ela sabe provém de sua própria experiência. Ela sempre foi tal como é agora. Não se modifica. Enxerga. Observa. Há algo acontecendo do outro lado. Ela pensa nisso. Mas continua em aberto a questão de se o que ela pensa corresponde ao que lá está sucedendo. Ela não tem meios de se convencer. É imóvel. E está só. O abismo é profundo demais. O golfo é intransponível. (Elias, 1994, p. 97).

São personagens que tudo fizeram, que tudo deram: trabalho, esforço, dedicação. De uma hora para outra, estão voltadas para um mundo reduzido, cujo alargamento se faz pela infinitude da memória. Mundos cristalizados pelos costumes, pela tradição, pelos papéis sociais: “O meu mundo é um, o dele é outro. Conversar é comigo mesmo, mas ele quer exclusividade com a patota dele. Então você vê quantas barreiras tenho para ter uma vida mais livre, então me sinto sozinha. Mas levo muito bem, obrigada", como bem sintetizou uma aposentada em relação aos dois mundos: o dela e do esposo.

A comunicação não é um novo criar, mas atos de uma incomunicabilidade pela falta do fazer conjunto, do compartilhar. O passado se torna presente pela memória, pela rememoração, pela rotina atualizada do que foi. A maior aproximação da presença é distância de experiências, que perde força para se transformar em "murmúrio do passado", de Baudelaire trazido para nós por Walter Benjamin (1975, p. 55). O trabalho e a família continuam como referências, como ato do relembrar e de anseio de encontrar amigos, ex-colegas, parentes. Assim cada um continua guiado pelo fantasma idealizado do passado. O presente-futuro o novo, o móvel, o comunicável se abre como perspectivas pelo desejo de construir alternativas, buscar o que fazer. O aposentado é um ser de esperanças, tanto no sentido de aguardar alguém que lhe ouça, que divida com ele as dificuldades do momento; quanto em confiar, esperar por melhores dias.

A voz da experiência é a do reconhecimento de uma vida de trabalho, de construção de uma família, de uma rede de amizades. Hoje, essa 
vOz é também continuidade de uma diferença de interesses, marcada por posições, encoberta pelo nome de aposentadoria, mas que carrega as marcas do homem e da mulher, do esposo e da esposa, do nível superior e do nível médio, de distinção salarial e de classe social, da pluralidade ideológica, religiosa, de pensamentos e idéias.

A aposentadoria traz o distanciamento, "sacrifica o círculo de amizades" dos ex-colegas e dos amigos - o que vai aumentando com o passar dos anos. Nos primeiros momentos, esforços são feitos em busca de uma regularidade, marca do trabalho, que soldem laços antigos. Para que o convívio não seja disperso, escasseado surge a constituição de um espaço próprio - sala dos aposentados -, realizações de reuniões, de encontros; celebrações ${ }^{6}$ de aniversários e de outras efemérides coletivas como Páscoa, Natal, aniversário da Instituição. São momentos onde histórias de ontem são relembradas, nomes citados, indagações repetidas, fatos do hoje narrados, exposições de vida e neles os anseios de aumento salarial, as opiniões sobre o andamento de ações administrativas e judiciais, os filhos casados, separados, trabalhando, "graças a Deus!", desempregados, "que governo!", os netos, as dificuldades do sair, a violência. São reposições de parcelas de um cotidiano ao mesmo tempo distante e atual. São abraços, promessas de novos encontros, de novas reuniões, de "não se deixar vencer pelo imobilismo", do "vamos nos encontrar".

Lendo e relendo as entrevistas, histórias e análises, recordando conversas e opiniões, em todos uma forte palavra parece ser voz e desejo: encontro. Trabalho, família, amigos são vozes de recordação, caminhos de encontro. São personagens que anseiam superar o isolamento: "procuro manter a sociabilidade, cultivando velhas e novas amizades" (Q.H.A., aposentado).

Sim porque o "que vou fazer em casa?" carrega em si o medo do isolamento, do trancar-se em si e em família. Problema que ganha dimensão de acordo com as condições locais. Se as cidades grandes oferecem mais oportunidades para o lazer, para outras ocupações, têm as dificuldades de locomoção, a distância, a pressão da violência, que estão em todas as falas, tudo isso obstaculizando os encontros, as festividades coletivas. As cidades médias ou pequenas com suas vantagens comparativas favorecem determinado tipo de qualidade de vida, longe da poluição, do corre-corre, do stress. Por outro lado, "o tempo não passa".

"Fazer o que em casa?” é também reclusão. Claro que existem aqueles aposentados que por falta de opções, de capacitação ou por outras razões 
"não têm mais força nem vontade para fazer mais nada" (M.M.J., aposentada), fazem da casa um local de tédio, de doença ${ }^{4}$, do não saber dela se utilizar:

As pessoas estão se aposentando, não sei se pressionadas pelo tempo já vencido, mas até onde conheço, muitas amigas não estão devidamente preparadas para aposentadoria, pois não sabem o que fazer. Vejo então um despreparo muito grande, o que traz as frustrações, as doenças de várias naturezas, elas engordam, não cuidam de si, não saem de casa. É inevitável. Ficam dentro de casa sem nenhuma objetividade, pelo menos com pessoas que eu conheço. (S.N.M., aposentada).

Situação que, como vimos, é real; mas também problematizada como preocupação, é temida pela probabilidade de sua realização e por isso são construídos mentalmente esquemas para evitá-la:

A questão mais importante é você estar sempre preocupado em manter uma atividade, qualquer que seja, para que se tenha objetivos, mesmo que pequenos, que mantenham a cabeça ocupada. Isso para não ficar preocupado com o tempo que não passa, ficar criando problemas, enfim, mudar o seu padrão de comportamento em função desse estresse de ficar nessa crise de inatividade. Então você tem que ter um preparo psicológico e começar a criar áreas de interesse que lhe permitam estar sempre de bem com a vida, na questão da cabeça. E também não descuidar da questão física. (S.H.S., aposentado).

Longe de se encontrar nesse depoimento veios de um receituário de pensamento positivo, ele contém elementos referentes à falta de preparação para a aposentadoria, tanto do ponto de vista psicológico, quanto de formação, aliás tema recorrente em várias entrevistas.

4 Em diversas ocasiões, ouvi referências ao aumento do alcoolismo no meio dos aposentados, especialmente entre os que não trabalham, sem que houvesse dados mais precisos. Formula-se a seguinte hipótese: sem dúvida não será muito mais do que já existia. Os problemas financeiros certamente estão contribuindo, mas por não puderem mais esconder o problema através de licenças médicas, de viagens, agora estão mais conhecidos. É uma explicação plausível, mas não a única. 
Estamos diante de um problema bastante sério que atinge uma quantidade muito grande de aposentados, independente de sexo, certamente mais presente no seio daqueles que não têm um curso superior. Dos quarenta e nove entrevistados, treze homens e onze mulheres estão com outras atividades, o que corresponde a quase $49 \%$ do universo da pesquisa. Mas a precariedade persiste, porque muitas dessas atividades são no setor terciário ou em cargos de confiança, que de uma ora para outra podem ser dispensados. Não queremos e não podemos tomar o universo de nossa pesquisa como espelho de uma situação generalizada de toda uma categoria. Todavia, o problema do desemprego na sociedade, e no nosso caso, de uma segunda alternativa de trabalho, aparecem nas falas dos entrevistados e estão estampados em jornais, boletins sindicais e associativos.

As causas e explicações são variadas. De uma aposentada que exerceu cargos de direção, inclusive na área de Recursos Humanos, a sua fala se baseia num raciocínio bipolar: entre aqueles que "participaram ativamente das atividades da Instituição, eles vão para a aposentadoria, mas não se aposentam. Não aposentam a cabeça, o trabalho. E muitos, não a grande maioria, já se aposentam pensando eu vou para tal lugar ocupar um DAS 5 ou um outro cargo. Eles se aposentam no papel, mas continuam a trabalhar ou no próprio Órgão ou em outros, pois detém o conhecimento e gostam do trabalho"; e os que "estão aposentados já na atividade, vão simplesmente trabalhar e voltam para casa, eles se aposentam e ficam em casa e não querem saber de mais nada" (G.M.L.M., aposentada).

Essa explicação sinteticamente formulada na classificação entre os que "vestem a camisa do trabalho e da Instituição e os que não a vestem" é recorrente em vários discursos e pode nos conduzir a uma análise funcionalista, seguindo os passos do sociólogo americano R. Merton.

Será simplismo dividir uma categoria, quantitativamente tão vasta, em dois pólos opostos, isto é, os que estão no exercício de novas atividades e aqueles que nada conseguiram. É um dado objetivo que muitos funcionários públicos considerados como bons ou excelentes funcionários conseguem outros empregos ou são convidados para cargos de confiança. Como também é verdade que entre esses, nem todos serão chamados,

5 É uma gratificação de nível superior para quem exerce chefia ou assessoria. 
com considerável probabilidade para os que exerciam atividades administrativas. Outros fatores como fama, prestígio, amizades funcionam como correia de transmissão para indicações, de tal maneira que, indiretamente, se constitui um sistema de "fazer a corte" a desempenhar um papel fundamental nas sugestões de nomes para cargos, pesquisas, em síntese, acesso aberto a novas oportunidades.

A falta de preparação e de uma capacitação mais aberta e mais além dos conhecimentos técnicos da Instituição, pesa e limita consideravelmente as oportunidades de inserção no competitivo mercado de trabalho, já inflacionado de jovens. O fator idade, mesmo sendo considerados “jovens-aposentados", 6 pesa negativamente, ou quando encontra é com salário reduzido e dentro de uma "política" de felicidade para a terceira idade.

Eu acho que o aposentado está com muita possibilidade de entrar no mercado de trabalho. Mas primeiro, existe o caso do preconceito da idade, e, segundo, há uma competição natural por novos cargos... O aposentado não tem, independente de sua formação, da sua capacidade, poder de competição com a faixa jovem. Contudo, acho que ele teria elementos importantes para contribuir, por sua experiência, sua vivência, principalmente para um melhor desenvolvimento da sociedade. (S.H.S., aposentado).

É esse capital, o da experiência, que alimenta, de um lado, esperanças de encontrar portas abertas para novas ocupações, e, de outro, que o torna mais cioso de seu passado. No entanto, entre as estruturas imaginativas e as estruturas reais o fosso está se tornando cada vez maior. A capacitação, sob formas variadas, que conduz à atualização e à aprendizagem de coisas novas é o mecanismo apontado, reclamado por todos, mas nem sempre de fácil acesso para aqueles que estão financeiramente com mais dificuldades, restabelecendo-se assim um círculo vicioso.

A capacitação para novas oportunidades de trabalho surge então como um contraponto à reclusão do lar, do permanecer em casa.

6 Dados governamentais apontavam, em 2002, para uma idade média do servidor público aposentado do Poder Civil em torno de 56 anos, mas no universo de nossa pesquisa era de 51,7. 


\section{Alguns apontamentos finais}

Os depoimentos transcritos revelam quão significativos são para a nova vida do aposentado o voltar e o permanecer integralmente em casa. De um lado, como construir e dinamizar novas relações cotidianas e como ser aposentado para si. Lembremo-nos de um depoimento: "eu não me pertenço". De outro, como ser visto pelos outros.

É nessa estrutura histórico-cultural agravada pela conjuntura econômica do Brasil, na época, que se forma a nova personalidade do aposentado, dessa nova categoria social. Os problemas financeiros e econômicos, comum a todos, predominam sobre as dificuldades de construção de um novo modo de vida social e cultural. A compreensão desse "fetiche" só foi possível pela explicitação nas entrevistas da diferenciação e distinção dos papéis masculinos e femininos. Se para as mulheres, mesmo as mais engajadas politicamente, o lar, a família, a casa não lhes traz o estigma do nada fazer, da improdutiva, para os homens, especialmente para aqueles que se aposentaram antes dos 60 anos, os valores predominantes na sociedade não lhes acenam a mesma simplicidade. Para o autor, as expressões “dedicação à família" pelos homens, e "volta ao lar" pelas mulheres traduzem a estrutura hierárquica masculina da sociedade, reforçada igualmente pela aceitação naturalizada da reprodução ampliada da jornada do trabalho feminino, conforme depoimentos da maioria das entrevistadas. O significado social do espaço e do tempo para o aposentado está estigmatizado por um padrão de comportamento e por uma estrutura de valores mais amplos da sociedade que se reproduzem, não sem conflitos, sob novas formas sociais.

\section{Referências bibliográficas}

BENJAMIN, Walter. Sobre alguns temas em Baudelaire. Textos Escolhidos. São Paulo: Ed. Abril, Col. Os Pensadores, v. 48, 1975.

DAMATTA, Roberto. A casa \& a rua: espaço, cidadania, mulher e morte no Brasil. $4^{\circ}$ ed. Rio de Janeiro: Editora Guanabra Koogan, 1991.

ELIAS, NOBERT. A Sociedade dos indivíduos. Tradução de Vera Ribeiro. Rio de Janeiro: Zahar, 1994.

GIDDENS, A. A constituição da sociedade. Tradução de Álvaro Cabral. São Paulo: Martins Fontes, 1989. 
VILAR, Abdias. O caminho do tempo: trajetória de vida do Serviço Público Federal. Campinas, IFCH-UNICAMP (Tese de Doutorado), 2002.

Resumo: Este artigo procura, partindo da metáfora "Vou fazer o que em Casa", compreender as representações sobre os papéis sociais da mulher e do homem na condição de aposentados. Os trechos das entrevistas citados revelam como no cotidiano as relações sociais estão marcadas, de um lado, pela subordinação do tempo livre do aposentado à disposição dos outros, resumidamente na coloquial expressão “já que...”; e por outro lado, mais pelos valores predominantes em relação ao homem e a mulher, e menos pelas condições econômicas. Para a mulher, a aposentadoria é o assumir completo a dupla jornada de trabalho, uma responsabilidade que lhe é cobrada não só pelos membros da família, mas pela sociedade em geral., não criando nenhuma incongruência de valores. $\mathrm{O}$ homem vive situação oposta, pois permanecer em casa tem um valor negativo de inutilidade, especialmente sobre o julgamento de uma prática tradicional do papel masculino "para fora de casa".

Palavras-chave: família; cotidiano; gênero; papel social feminino.

\section{What Shall I Do at Home?}

Abstract: Considering the metaphor "what shall I do at home?", this article intends to understand the representation of the social roles played by woman and man in their conditions as retired. The interview's exctract mentioned reveal how much this new sociability is determined by the subordination of the retired's free time to others. To woman, to retire means to assume completely a full time shift at home a position required not only by the family members but also by the society in general (however, do not motivating a value's conflict). Man deals with a different situation, because for him to stay at home implies in the negative idea of "worthless person" especially related to the judgement of a traditional practice of the male's role that is to be "out of home".

Keywords: family; daily life; gender; female social role. 
